Sains Malaysiana 46(5)(2017): 677-684

http://dx.doi.org/10.17576/jsm-2017-4605-01

\title{
Uniaxial Compressive Strength of Antarctic Peninsula Rocks: Schmidt Hammer Rebound Test
}

(Kekuatan Mampatan Sepaksi Batuan Semenanjung Antartik : Ujian Pantulan Tukul Schmidt)

\author{
Goh Thian Lai*, Nur Amanina MaZlan, Mohd Shahrul Mohd NadZIR, AbDUl GHani RafeK, \\ Ailie Sofyiana Serasa, AZIMAH Hussin, LeE Khai ERn \& FoONG SweE YeOK
}

\begin{abstract}
The uniaxial compressive strength test is a destructive and time consuming test. A number of non-destructive methods using portable testing equipment are more applicable and easier to conduct. This paper presents the results of a systematic approach to determine the uniaxial compressive strength of rock material using the Schmidt hammer rebound test. A total of five distinct locations (Graham Coast, Davis Coast, Nanson Island, Danco Coast and Trinity Island) were tested using the Schmidt rebound hammer test. Peninsula Antarctic located at northwest of Antarctic region comprising of igneous and metamorphic rocks. Statistical analysis of the results at 95\% confidence level showed the Schmidt rebound value of the Graham Coast ranges from $40 \pm 1.7$ to $41 \pm 1.3$ with standard deviation of 8.2 to 6.4. The rebound value for Davis Coast was 39 \pm 1.6 with standard deviation of 7.7. Rocks from Nanson Island and Danco Coast have the Schmidt rebound value of $54 \pm 1.7$ with standard deviation of 8.0 and $36 \pm 1.3$ with standard deviation of 6.2 , respectively. The Schmidt rebound value of rocks at Trinity Island ranges from $29 \pm 1.4$ to $32 \pm 1.7$ with standard deviation of 6.8 to 8.1 . Thus, the respective uniaxial compressive strengths of rock materials from Graham Coast, Davis Coast, Danco Coast, Nanson Island and Trinity Island were 73-108, 50, 59, 164 and 45-59 MPa. The respective ISRM strength classification of rock materials of Graham Coast, Davis Coast, Danco Coast, Nanson Island and Trinity Island were strong (R4) to very strong rock (R5), medium strong rock $(R 3)$, strong rock $(R 4)$, very strong rock $(R 5)$ and medium strong $(R 3)$ to strong rock $(R 4)$. The results showed a mean of quantification of rock material strength based on the Schmidt Hammer rebound test in Antarctic Peninsula.
\end{abstract}

Keywords: Rock material; Schmidt hammer rebound value; uniaxial compressive strength

ABSTRAK

Ujian kekuatan mampatan sepaksi adalah ujian memusnah dan memakan masa. Beberapa kaedah tidak-musnah yang menggunakan peralatan ujian mudah alih adalah lebih diterima pakai dan mudah untuk dijalankan. Kertas ini membentangkan keputusan menggunakan pendekatan yang sistematik untuk menentukan kekuatan mampatan sepaksi bahan batu dengan menggunakan ujian pantulan tukul Schmidt. Sebanyak lima lokasi (Pantai Graham, Pantai Davis, Pulau Nanson, Pantai Danco dan Pulau Trinity) telah diuji menggunakan ujian pantulan tukul Schmidt. Semenanjung Antartik yang terletak di barat laut Wilayah Antartik terdiri daripada batuan igneus dan metamorfik. Keputusan analisis statistik pada tahap keyakinan 95\% menunjukkan nilai pantulan Schmidt pantai Graham berjulat dari $40 \pm 1.7 \mathrm{ke} 41 \pm 1.3$ dengan sisihan piawai sebanyak 8.2 ke 6.4. Nilai pantulan pantai Davis adalah $39 \pm 1.6$ dengan sisihan piawai sebanyak 7.7. Batuan dari Pulau Nanson dan Pantai Danco mempunyai nilai pantulan Schmidt masing-masing sebanyak $54 \pm 1.7$ dengan sisihan piawai 8.0 dan 36 \pm 1.3 dengan sisihan piawai sebanyak 6.2. Nilai pantulan Schmidt untuk batuan di Pulau Trinity adalah dari $29 \pm 1.4$ hingga $32 \pm 1.7$ dengan sisihan piawai sebanyak 6.8 ke 8.1. Oleh itu, kekuatan mampatan sepaksi bahan batuan masing-masing dari Pantai Graham, Pantai Davis, Pantai Danco, Pulau Nanson dan Pulau Trinity adalah 73-108, 50, 59, 164 dan 45-59 MPa. Pengelasan kekuatan ISRM bahan batuan untuk Pantai Graham, pantai Davis, Pantai Danco, Pulau Nanson dan Pulau Trinity masing-masing adalah kuat (R4) ke batuan yang sangat kuat (R5), batuan sederhana kuat (R3), batuan kuat (R4), batuan sangat kuat (R5) dan sederhana kuat (R3) ke batuan kuat (R4). Keputusan ini menunjukkan satu purata kekuatan bahan batuan secara kuantitatif berdasarkan ujian pantulan tukul Schmidt di Semenanjung Antartik.

Kata kunci: Bahan batuan; kekuatan mampatan sepaksi; nilai pantulan tukul Schmidt

\section{INTRODUCTION}

The uniaxial compressive strength (UCS) is one of the important rock mechanics parameters for the determination of rock material strength and rock strength classification.
However, it is a destructive and time consuming method as suggested by the International Society for Rock Mechanics, ISRM (1978). A few geomechanics related studies in Antarctic Peninsula were reported by Elliot (2006), Rist 
(1996) and Selby (1980). Most of the researchers focused on the tectonics evolution of Gondwana drift (Fitzgerald 2002; Larter et al. 2002). Other research was about the weathering of rock, for example, Christine (2000) conducted studies on the relationships of the properties of the rock to salt, free-thaw, hydration and insolation weathering in Antarctic and Northern Hemisphere and physical rock weathering along the Victoria Land Coast. Thus, this research was conducted systematically to determine the uniaxial compressive strength of rock material of the selected areas in the Antarctic Peninsula by using Schmidt hammer rebound test. The application of indirect methods are relatively simple and generally do not require any sample preparation. The UCS value however, can be determined by using a mathematical model (Murat et al. 2011). The measurement of surface hardness is based on rebound index that depends on energy losses due to friction during acceleration and rebound of the hammer mass (Szilágyi \& Borosnyó 2009). According to Güney et al. (2005), the Schmidt hammer can be used to predict the uniaxial compressive strength of rocks, the performances of tunnel boring machines (TBM), advance speed of drilling machines as well as the evaluation of discontinuities in rock formations. There exist several established empirical relationships for the determination of uniaxial compressive strength for different rock types, as proposed by Aufmuth (1973), Deere and Miller (1966), Güney et al. (2005), Karaman and Kesimal (2015), Katz et al. (2000), Ramli Nazir et al. (2013), Shalabi et al. (2007), Singh et al. (1983), Tabatabaei (2003) and Torabi et al. (2010).

\section{METHODS}

The Schmidt hammer L- type was used in this study has an energy impact of $0.735 \mathrm{Nm}$. A total of 630 readings of in-situ Schmidt hammer rebound values were taken. The study locations (Figure 1) were at Graham Coast, Davis Coast, Danco Coast, Nanson Island and Trinity Island. Ninety in-situ readings were obtained from each location. The calibration of Schmidt hammer rebound readings were calculated according to the ISRM (1978). The Schmidt hammer rebound readings were analysed using

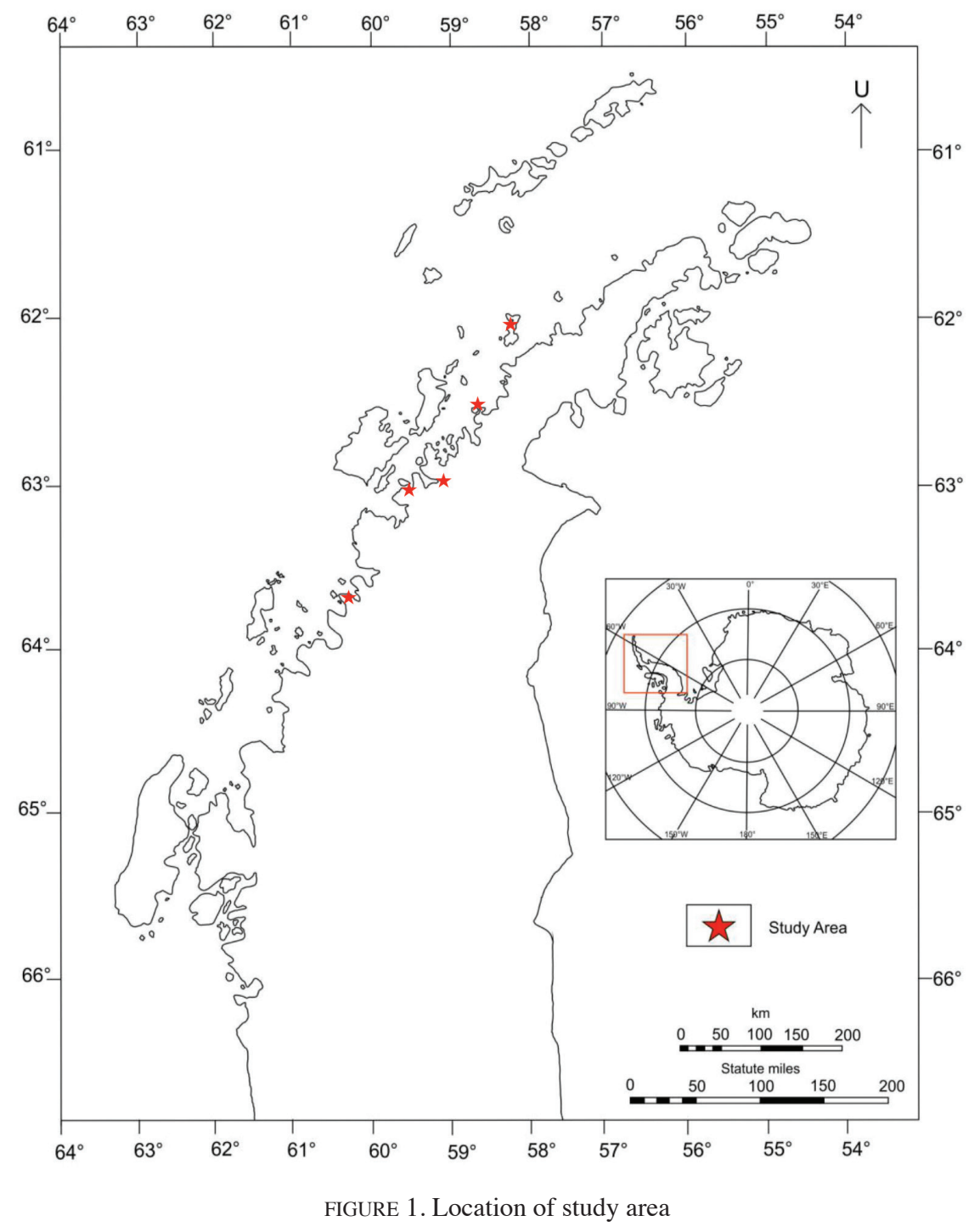


SPSS-statistical version 16 at $95 \%$ confident level. Onesamples-T test was used to determine the mean value of the Schmidt hammer rebound readings. The determination of uniaxial compressive strength was obtained from the empirical formula by Deere and Miller (1966) using the Schmidt hammer rebound value and dry density of rocks. Dry density tests were conducted using the irregular shape of rock samples. The volume of rocks samples were obtained from water displacement method. The rest of the procedure was conducted according to the ISRM (1978). Figure 2 shows the Schmidt hammer test conducted at Graham Coast.

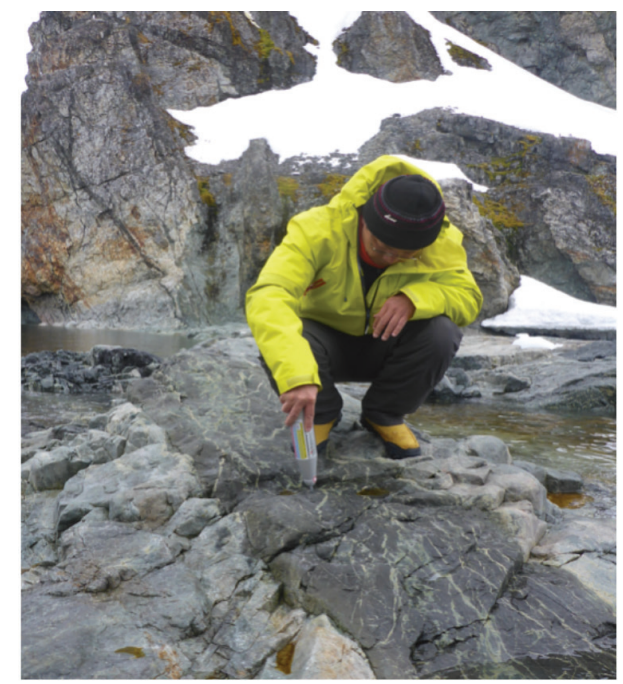

FIGURE 2. Schmidt hammer rebound test at Graham Coast, Antarctic Peninsula

\section{GEOLOGY OF ANTARCTICA}

Antarctic bedrocks are mostly covered by $99 \%$ of ice with thickness of $4700 \mathrm{~m}$ (Riffenburgh 2007). The geological map of Peninsula Antarctic was shown in Figure 3. Only $2 \%$ of the continent is ice free (Harley 2007). The limited exposed bedrock allowed the study of the tectonic activities and geological processes. Despite the lack of exposed outcrop, the geology of Antarctic was widely and clearly explained by several authors; Adie (1962), Eagles (2003), Elliot (1975), Fitzgerald (2002), Guild et al. (1998) and Harley et al. (2013). According to Adie (1962) and Harley (2007), Antarctic is divided into Eastern Antarctica that is dominated by Precambrian rocks of the East Antarctic Shield and covered with main polar ice cap and Western Antarctic that consist of Mesozoic and Cenozoic rocks. East Antarctic Shield comprises of Permian-Triassic sediments overlying older metamorphic rocks and these sediments are intruded by Jurassic mafic magmatism that consists of dyke swarms and plateau basalts (Harley 2007). The Trans Antarctic Mountains consist of thick sedimentary sequences, doleritic sills and basaltic lavas overlying metamorphic rock followed by the intrusion of granitic rock (Harley 2007). The west
Antarctic is composed of arc-related igneous rocks, arcrelated sedimentation and Cenozoic magmatism (Harley 2007). According to Adie (1962), two different provinces named Andean and Gondwana made up the Antarctic land which gave rise to the geological differences in both East Antarctic and West Antarctic. Elliot (1975) suggested the geological differences between East and West Antarctic was due to major structural break extending across the continent. Adie (1962) stated that the climate of Antarctica has undergone several reversals upon the interpretation of fossil flora and fauna. At least two episodes of warm climate recorded in Antarctica histories during Devonian to Carboniferous that deposited river sands and marine sediments with fossils and Permian to Triassic which deposited river sands and coal bed that indicates the presence of forest and animals (Riffenburgh 2007). The cooling stage of Antarctic land was referred to as Permian Glaciation (Riffenburgh 2007). The development of ice sheets in 34-45 Ma and mountain formation eroded Tertiary sediments into basins such as Ross Sea (Riffenburgh 2007). The recent climate of Antarctica was explained in both the studies from Adie (1962) and (Majewski 2000). The deterioration of Antarctic climate to permanently refrigerated conditions can be observed after temperate to sub-tropical climate in Middle Jurassic which supporting the growth of flora (Adie 1962). The drilling data of $1.5 \mathrm{~km}$ sediments showed progressive cooling process, causing the disappearance of forest and the formation of permanent ice sheets (Majewski 2000).

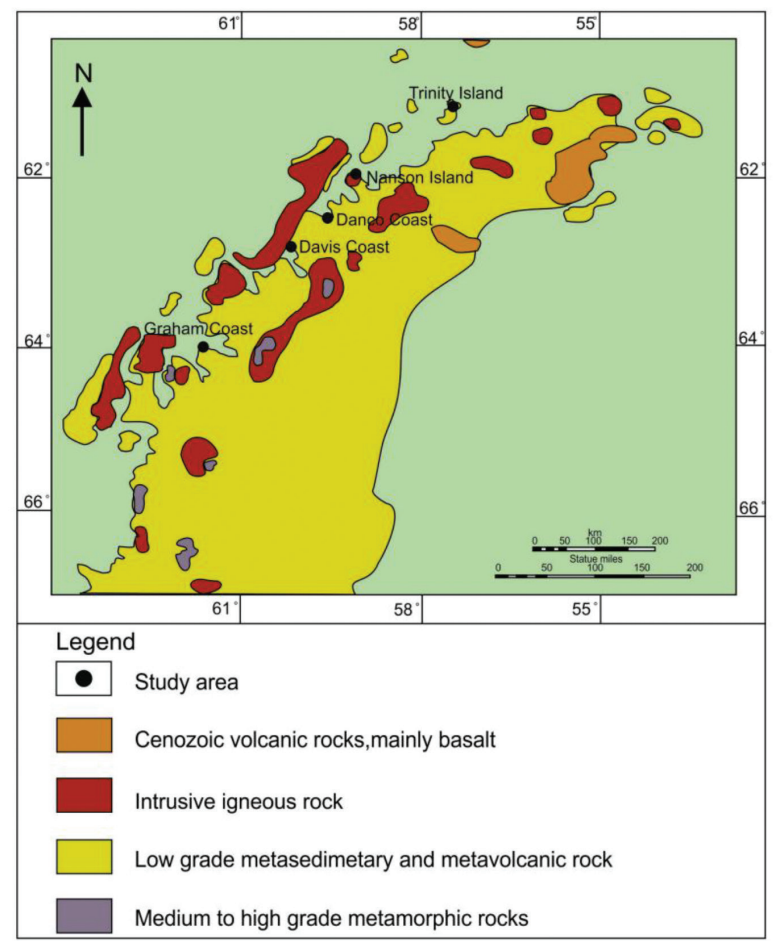

FIGURE 3. Geological map of Peninsula Antarctic Source: Modified from Craddock (1970) 


\section{RESULTS AND DISCUSSION}

Eight hand samples were collected from the study area comprising of igneous and sedimentary rocks (Figure 4). The information and description of the hand samples are displayed in Table 1. The dry densities of samples were determined as exhibited in Table 2. Generally the dry densities of rock in Antarctic Peninsula range from 27 to $23 \mathrm{kN} / \mathrm{m}^{3}$. The samples from Graham Coast have the highest dry density value of $27 \mathrm{kN} / \mathrm{m}^{3}$. The samples from Davis Coast has the lowest dry density value of $23 \mathrm{kN} / \mathrm{m}^{3}$.

Boxplot of Schmidt hammer readings $(\mathrm{R})$ for respective locations are displayed in Figure 5. The summary statistical analysis of mean, standard deviation, median, skewness and mode are displayed in Table 2. Negative skewness represent a condition in which more result have higher value $(>50 \%)$ than the mean value of R. Positive skewness represent a condition in which more result have lower value $(<50 \%)$ than the mean value of $\mathrm{R}$.

Statistical analysis of the results at $95 \%$ confidence level showed the Schmidt rebound value of igneous rocks in Graham Coast ranges from $40 \pm 1.7$ to $41 \pm 1.3$ with standard deviation of 8.2 to 6.4. For rock in Davis Coast, the rebound value was $39 \pm 1.6$ with standard deviation of 7.7. Rock from Nanson Island and Danco Coast has the Schmidt rebound value of $54 \pm 1.7$ with standard deviation of 8.0 and $36 \pm 1.3$ with standard deviation of 6.2 , respectively. The Schmidt rebound value of rock at Trinity Island ranges from $29 \pm 1.4$ to $32 \pm 1.7$ with standard deviation of 6.8 to 8.1 (Table 2).

The result showed that a large range of Uniaxial Compressive Strength (UCS) values were obtained from Antarctic Peninsula rocks using the correlation of Deere and Miller (1966) (Table 2). Thus, the respective uniaxial compressive strengths of rock materials for the rocks from Graham Coast, Davis Coast, Danco Coast, Nanson Island and Trinity Island were 73-108, 50, 59, 164 and 45-59 MPa. The highest UCS value of $164 \mathrm{MPa}$ was recorded in Nanson Island. The lowest UCS value of $45 \mathrm{MPa}$ was recorded in Trinity Island (Table 2).

According to strength grade by ISRM (1978), the strength value of rocks was graded from very strong rock to medium strong rock, (R5-R3). The samples in
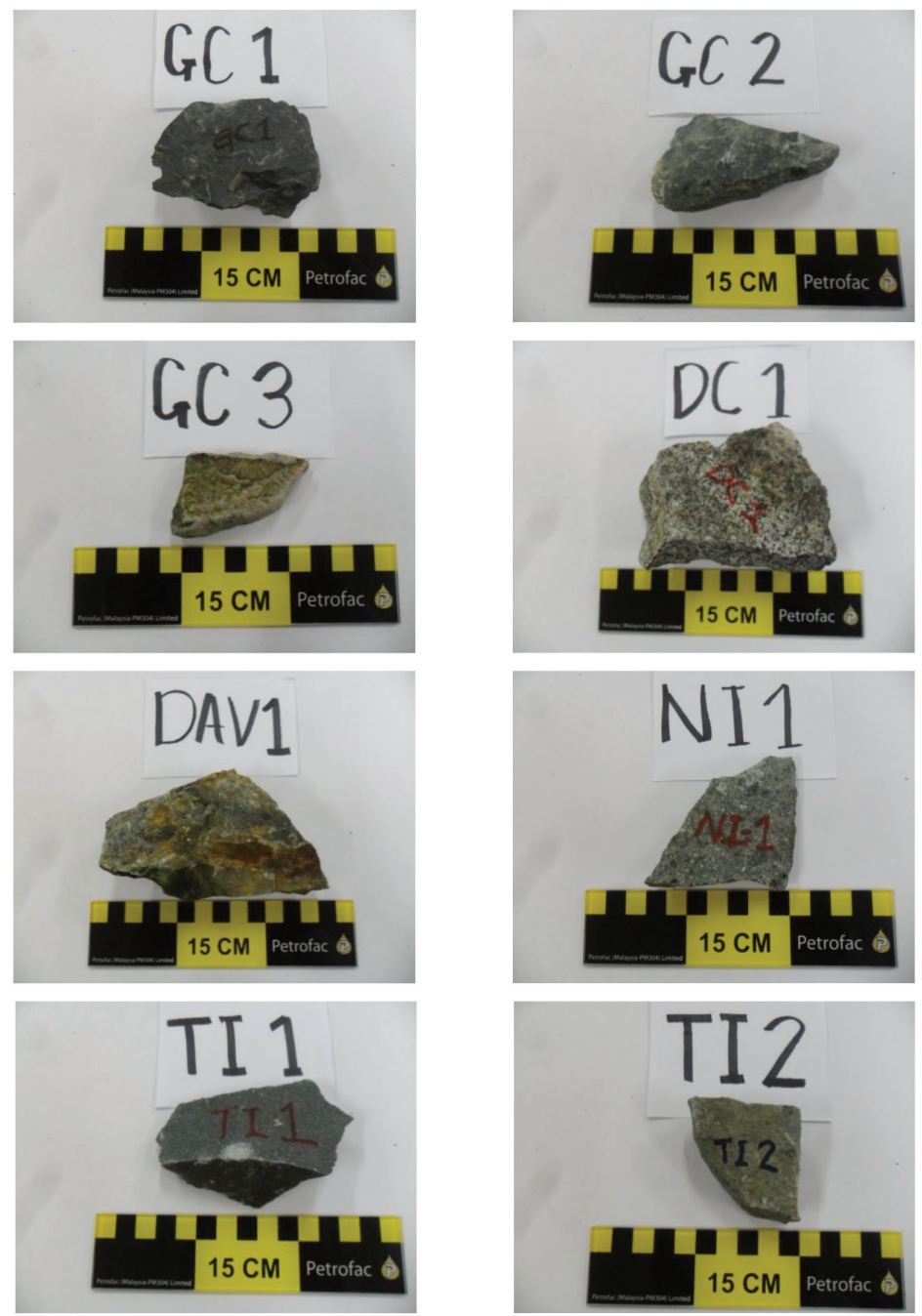

FIGURE 4. The hand samples from Graham Coast (GC1, GC2, GC3), Davis Coast (DAV1), Danco Coast (DC1), Nanson Island (NI1), Trinity Island (TI1 ,2) 
TABLE 1. Description of the hand samples

\begin{tabular}{|c|c|c|c|}
\hline Location & Samples & Coordinate & Descriptions \\
\hline \multirow[t]{3}{*}{ Graham Coast } & GC1 & $\begin{array}{l}\text { S } 65^{\circ} 24^{\prime} 33.73^{\prime \prime} \\
\text { W } 64^{\circ} 14^{\prime} 5.46^{\prime \prime}\end{array}$ & Very fine grained dark grey rock with quartz veins, igneous rock \\
\hline & GC2 & & $\begin{array}{l}\text { Fine grained aphanitic texture light greenish grey rock with white } \\
\text { yellowish vein, igneous rock }\end{array}$ \\
\hline & GC3 & & $\begin{array}{l}\text { Fine grained pinkish aphanitic texture rock, igneous rock, probably } \\
\text { rhyolite Mineral forming rock such as quartz }(40 \%) \text {, alkali feldspar } \\
(30 \%) \text { and plagioclase }(30 \%) \text {, igneous rock }\end{array}$ \\
\hline Danco Coast & DC1 & $\begin{array}{l}\text { S } 65^{\circ} 4^{\prime} 4.90^{\prime \prime} \\
\text { W } 64^{\circ} 1 ' 54.65^{\prime \prime}\end{array}$ & $\begin{array}{l}\text { Light grey with phaneritic texture, mineral forming rock such as } \\
\text { quartz }(30 \%) \text {, alkali feldspar }(20 \%) \text {, plagioclase }(20 \%) \text {, biotite }(40 \%) \\
\text { hornblend }(20 \%) \text {. Mineral size ranging from } 1-5 \mathrm{~mm} \text { (intermediate } \\
\text { grain size), igneous rock }\end{array}$ \\
\hline Davis Coast & DAV 1 & $\begin{array}{l}\mathrm{S} 64^{\circ} 54^{\prime} 12.46^{\prime \prime} \\
\mathrm{W} 62^{\circ} 52^{\prime} 1.89^{\prime \prime}\end{array}$ & $\begin{array}{l}\text { Light grey, aphanitic texture with pyrite randomly disperse all over } \\
\text { the rock, igneous rock }\end{array}$ \\
\hline Nanson Island & NI 1 & $\begin{array}{l}\text { S } 64^{\circ} 32 ’ 21.94^{\prime \prime} \\
\text { W } 61^{\circ} 59^{\prime} 40.81^{\prime \prime}\end{array}$ & $\begin{array}{l}\text { Light greenish grey, coarse grain with porphyritic texture, largest } \\
\text { phenocryst size up to } 15 \mathrm{~mm} \text { and black in colour, white mineral are } \\
\text { smallest in grain size ( } 1 \mathrm{~mm}-3 \mathrm{~mm}) \text {, igneous rock }\end{array}$ \\
\hline \multirow[t]{2}{*}{ Trinity Island } & TI 1 & $\begin{array}{l}\text { S } 63^{\circ} 54^{\prime} 9.59^{\prime \prime} \\
\text { W } 60^{\circ} 47^{\prime} 25.12^{\prime \prime}\end{array}$ & $\begin{array}{l}\text { Dark grey, aphanitic texture with quartz as phenocryst sized up to } 2 \\
\text { mm. Existing of quartz veins, igneous rock }\end{array}$ \\
\hline & TI 2 & & $\begin{array}{l}\text { Light greenish grey with three different shape, colour and size of clast } \\
\text { Porous surface. Largest clast size in dark grey colour }(2-10 \mathrm{~mm}) \\
\text { smallest clast in white size from } 1-3 \mathrm{~mm} \text {. Another clast is brown in } \\
\text { colour with grain size of } 2-4 \mathrm{~mm} \text {, sedimentary rock }\end{array}$ \\
\hline
\end{tabular}

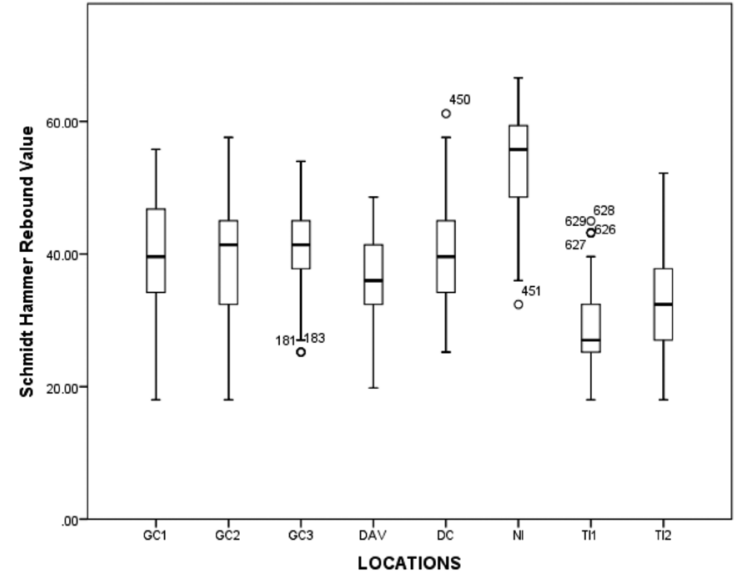

FIGURE 5. Boxplot of Schmidt hammer rebound values for Graham Coast (GC1, GC2 and GC3), Davis Coast (DAV), Danco Coast (DC), Nanson Island (NI), Trinity Island (TI1 and TI2)

Graham Coast and Nanson Island were graded as strong to very strong rock with UCS values of 108 and $164 \mathrm{MPa}$, respectively. Both samples from Davis Coast and Trinity Island, TI1 were graded as medium strong rocks with UCS values of 50 and $45 \mathrm{MPa}$. Second sample from Trinity Island, TI2, Graham Coast, GC2 and sample from Danco Coast were graded as strong rock with the UCS values of 59, 73 and $59 \mathrm{MPa}$, respectively. The respective strength classification of rock materials of Graham Coast, Davis Coast, Danco Coast, Nanson Island and Trinity Island were strong (R4) to very strong rock (R5), medium strong rock (R3), strong rock (R4), very strong rock (R5) and medium strong (R3) to strong rock (R4) (Table 2). The rock strength for previous study shows that the igneous rocks were classified as strong rock (R5). According to Lim et al. (2015), the average value of igneous rock in Peninsula Antarctic tested at King Sejong Station for diorite, granodiorite and andesite were 147, 136 and 117 $\mathrm{MPa}$, respectively.

\section{CONCLUSION}

This study determined the uniaxial compressive strength of rocks from selected areas in Antarctic Peninsula using Schmidt hammer rebound values. The Schmidt rebound value of igneous rocks in Graham Coast ranges from $40 \pm$ 1.7 to $41 \pm 1.3$ with standard deviation of 8.2 to 6.4 . For rocks in Davis Coast, the rebound value was $39 \pm 1.6$ with standard deviation of 7.7. Rocks from Nanson Island and Danco Coast has the Schmidt rebound value of $54 \pm 1.7$ with standard deviation of 8.0 and $36 \pm 1.3$ with standard deviation of 6.2 , respectively. The Schmidt rebound value of rocks at Trinity Island ranges from $29 \pm 1.4$ to $32 \pm 1.7$ with standard deviation of 6.8 to 8.1 . Thus, the respective uniaxial compressive strengths of rock materials for the igneous rocks from Graham Coast, Davis Coast, Danco Coast, Nanson Island and Trinity Island were 73-108, 50, 59, 164 and 45-59 $\mathrm{MPa}$, respectively. The rocks in that area were classified as very strong rock (R5) to medium 


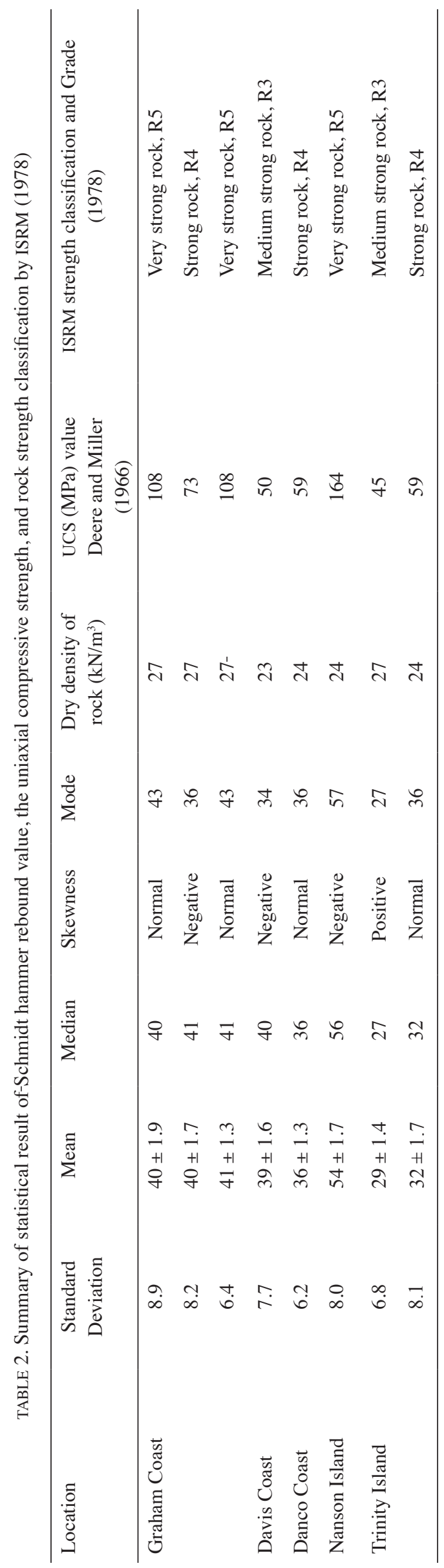


strong rock (R3) according to the ISRM (1978). These results represent a means of quantification of rock material strength based on the Schmidt Hammer rebound values.

\section{ACKNOWLEDGEMENTS}

This publication is based on work supported by the Government of Malaysia under grant Fundamental Research Grant Scheme FRGS/1/2014/STWN06/UKM/02/1, GUP2016-024 and e-Science Fund Grant Scheme 06-01-02-SF 1140. The authors would also like to acknowledge the support of Sultan Mizan Antarctic Research Foundation, the staff and facilities at Geology Program and Faculty of Science and Technology, Universiti Kebangsaan Malaysia.

\section{REFERENCES}

Adie, A.J. 1962. The geology of Antarctica. Antarctic Research: The Matthew Fontaine Maury Memorial Symposium 7: 26-38.

Aufmuth, R.E. 1973. A systematic determination of engineering criteria for rocks. Bull. Assoc. Eng. Geol. 11: 235- 245.

Craddock, C. 1970. Tectonic Map of Antarctica. New York: American Geographical Society.

Christine, E. 2000. A review of rock weathering in Antarctica and its relationship to studies in the Northern Hemisphere. GCAS. University of Canterbury (Unpublished).

Deere, D.U. \& Miller, R.P. 1966. Engineering classification and index properties for intact rocks. Tech Report Air Force Weapons Lab. pp. 65-116.

Eagles, G. 2003. Tectonic evolution of the Antarctic Phoenix plate system since $15 \mathrm{Ma}$. Earth and Planetary Science Letters 217: 97-109.

Elliot, D.H. 1975. Tectonics of Antarctica: A review. American Journal of Science 275: 45- 106.

Elliott, C.E. 2006. Physical rock weathering along the Victoria Land Coast, Antarctica. PhD Dissertation, University of Canterbury (Unpublished).

Fitzgerald, P. 2002. Tectonics and landscapes evolution of the Antarctic plate since the breakup of Gondwana, with an emphasis on the West Anatrctic Rift System and the Transantarctic Mountains. Royal Society of New Zealand Bulletin 35: 453-469.

Guild, P.W.,Piper, D.Z., Lee, M.P., McCoy, F.W., Manhein, F.T., Lane-Bostwick, C.M., Swint-Iki, T.R., Grye, G. \& Luepke, G. 1998. Explanatory notes for the mineral-resources map of the Circum-Pacific Region Antarctic sheet. US. Geological Survey.

Güney, A., Altındağ, R., Yavuz, H. \& Saraç, S. 2005. Evaluation of the relationships between schmidt hardness rebound number and other (engineering) properties of rocks. The 19th International Mining Congress and Fair of Turkey 19: 83-89.

Harley, S.L. 2007. The geology of Antarctica. Encyclopedia of Life Support Systems.

Harley, S.L., Fitzsimons, I.C.W. \& Yue, Z. 2013. Antarctica and supercontinent evolution: Historical perspectives, recent advances and unresolved issues. Geological Society, London. 383: $1-34$

Lim, H-S., Jang, B-A., Kim, J-H. \& Kang, S-S. 2015. Estimation of R-value and uniaxial compressive strength of rocks around the King Sejong Station, Barton Peninsula, Antarctica from SilverSchmidt Q-value. Tunnel \& Underground Space 25(2): 199-209.
ISRM. 1978. Suggested methods for the quantitative description of discontinuities in rock masses. International Journal Rock Mechanics Mining Science and Geomechanics Abstract 15: 319-368.

Karaman, K. \& Kesimal,A. 2015. Correlation of Schmidt rebound hardness with uniaxial compressive strength and P- wave velocity of rock materials. Arabian Journal for Science and Engineering 40(7): 1897-1906.

Katz, O., Reches, Z. \& Roegiers, J.C. 2000. Evaluation of mechanical rock properties using a Schmidt hammer. Int. J. Rock Mech. Min. Sci. 37: 723-728.

Larter, R.D., Cunningham, A.P., Barker, P.F., Gohl, K. \& Nitsche, F.O. 2002. Tectonic evolution of the Pacific margin of Antarctica 1. Late Cretaceous tectonic reconstructions. Journal of Geophysical Research 107(B12): EPM 5-1-EPM 5-19.

Majewski, W. 2000. Cape Roberts Project: Investigating the Cenozoic history of Antarctica. Polish Polar Research 21(2): 89-97.

Murat Yurdakul, Ceylan,H. \& Akdas, H. 2011. A predictive model for uniaxial compressive strength of carbonate rocks from Schmidt hardness. Civil, Construction and Environmental Engineering Conference Presentations and Proceedings. p. 7.

Ramli Nazir, Momeni, E., Armaghani, D.J. \& Amin, M.F.M 2013. Prediction of unconfined compressive strength of limestone rock samples using L-type Schmidt hammer. EJGE 18: 1768-1775.

Riffenburgh, B. 2007. Encyclopedia of the Antarctic. London, Routledge: Taylor and Francis Group.

Rist, M.A., Sammonds, P.R., Murrell, S.A.F., Meredith, P.G., Oerter,H. \& Doake, C.S.M. 1996. Experimental fracture and mechanical properties of Antarctic ice: Preliminary results. Ann. Glaciol. 23: 284-292.

Selby, M.J. 1980. A rock mass strength classification for geomorphic purposes: With tests from Antarctica and New Zealand. Z. Geomorpho. 24: 31-51.

Shalabi, F.I., Edward, J.C. \& Al-Hattamleh, O.H. 2007 Estimation of rock engineering properties using hardness tests. Engineering Geology 90: 138-147.

Singh, R.N., Hassani, F.P. \& Elkıngton, P.A.S. 1983. The application of strength and deformation index testing to the stability assessment of coal measures excavations Proc.24th US Symp. on Rock Mech., Texas A\&M Univ. AEG Balkema, Rotterdam. pp. 599-609.

Szilágyi, K. \& Borosnyói, A. 2009. 50 years of experience with the Schmidt rebound hammer. Concrete Structure.

Tabatabaei, S.H. 2003. Assessment of Schmidt rebound hammer for determination of uniaxial compressive strength. Journal of Engineering Geology 1(3): 271 -280.

Torabi, S.R., Ataei, M. \& Javanshir, M. 2010. Application of Schmidt rebound number for estimating rock strength under specific geological conditions. Journal of Mining \& Environment 1(2): 1- 8.

Goh Thian Lai*, Nur Amanina Mazlan, Mohd Shahrul Mohd Nadzir \& Azimah Hussin

School of Environmental and Natural Resource Sciences

Faculty of Science and Technology

Universiti Kebangsaan Malaysia

43600 UKM Bangi, Selangor Darul Ehsan

Malaysia 
Abdul Ghani Rafek

Department of Geosciences

Universiti Teknologi PETRONAS, Bandar Seri Iskandar

31750 Tronoh, Perak Darul Ridzuan

Malaysia

Ailie Sofyiana Serasa

Chemical and Petroleum Engineering Department

Faculty of Engineering, Technology and Built Environment

UCSI University, 56000 Cheras

Kuala Lumpur, Federal Territory

Malaysia

\section{Lee Khai Ern}

Institute for Environment and Development (LESTARI)

Universiti Kebangsaan Malaysia

43600 UKM Bangi, Selangor Darul Ehsan

Malaysia
Foong Swee Yeok

School of Biological Science

Universiti Sains Malaysia, Minden

11800 Penang, Pulau Pinang

Malaysia

*Corresponding author; email: gdsbgoh@gmail.com

Received: 27 May 2016

Accepted: 18 October 2016 